\title{
ІНФОРМАЦІЙНИЙ МЕХАНІЗМ РЕАЛІЗАЦІї СЕРВІСНО-ОРІЄНТОВАНОЇ ДЕРЖАВНОї ЕКОЛОГІЧНОЇ ПОЛІТИКИ В УКРАЇНІ
}

\section{THE INFORMATION MECHANISM OF IMPLEMENTATION SERVICE-ORIENTED STATE ENVIRONMENTAL POLICY IN UKRAINE}

у статmі визначено ключові характеристики поняття «сервісна держава» в роботах вітчизняних науковців та запропоновано сервісні підходи в управлінні перенести до сорери екології. Розглянуто інорормаційний механізм реалізації сервісно-орієнтованої державної політики в екологічній сорері з точки зору побудови взаємин держави з громадськістю за принципом «знизу - догори», за якого громадськість, міжнародні фронди, об'єднання громадян слугують ініціаторами ухвалення важливих рішень в екологічній сорері та беруть активну участь у розробиі, прийнятті та контролі за їх реалізацією. Проведено аналіз основних нормативно-правових документів у зазначеній сорері та аналіз нормативного закріплення екологічних прав громадян в Україні. Визначено детермінанти формування сервісно-орієнтованої державної екологічної політики на сучасному етапі розвитку України, серед яких - децентралізаційні процеси передачі урядом повноважень на рівень, ближчий до споживача; залучення громадськості до роботи органів влади та профрільних інститучій у сорері екології; використання комунікативних технологій планування та здійснення контролю, а також електронних (цифрових) засобів комунікації влади і громадян. Автором зроблено висновок, що ефективність ффункціонування державної екологічної політики полягає в ефективності задоволення потреб споживачів, а також швидкості й ефективності обміну інорормаційними потоками, в тому числі з допомогою сучасних інфрормаційно-комунікаційних технологій. У статті учасниками процесу виділено державу та ключові інсти туції у сорері екології, з одного боку, та громадськість - з іншого. Підкреслено також, що сучасну державну політику в екологічній сорері можна вважати сервісно-орієнтованою через спрямованість держави на задоволення потреб громадськості, в тому числі на отримання доступу до екологічної інформації.

Ключові слова: інсрормачійний механізм сервісно-орієнтована держава, екологічна сорера, екологічні права, реалізація сервісно-орієнтованої державної екологічної політики.

The article identifies the key characteristics of the concept of "service state" in the works of domestic scientists and proposes to transfer service approaches in management to the field of ecology. The information mechanism of realization of service-oriented state policy in the ecological sphere from the point of view of building of relations of the state with the public on the principle "from bottom to top" is considered, under which the public, international funds, associations of citizen's participation in the development, adoption and control over their implementation. The analysis of the basic normative-legal documents in the specified sphere and the analysis of normative fixing of ecological rights of citizens in Ukraine is carried out. The determinants of the formation of service-oriented state environmental policy at the current stage of development of Ukraine have been identified, including: decentralization processes of government transfer of powers to a level closer to the consumer; public involvement in the work of authorities and relevant institutions in the field of ecology; use of communication technologies of planning and control, as well as electronic (digital) means of communication between government and citizens. The author concludes that the effectiveness of the state environmental policy is the effectiveness of meeting the needs of consumers, as well as the speed and efficiency of information exchange, including through modern information and communication technologies. In the article, the participants in the process identified the state and key institutions in the field of ecology, on the one hand, and the public - on the other. It is also emphasized that the modern state policy in the environmental sphere can be considered service-oriented due to the state's focus on meeting the needs of the public, including access to environmental information

Key words: information mechanism, service-oriented state, ecological sphere, ecological rights, implementation of service-oriented state ecological policy.
Постановка проблеми у загальному вигляді. Нині в Україні відбувається поступова трансформація державного управління до сервісно-орієнтованого управління, зокрема й у сфері екології. Серед іншого такі трансформації спричиняють зміни в інформаційно-комунікаційних процесах держави. Питання доступу громадян до своєчасної, достовірної інформації про стан навколишнього природного середовища, наявні екологічні ризики й загрози не втрачає своєї актуальності. Під впливом такого суспільного запиту постає необхід- ність науково-теоретичного обґрунтування сутності та змісту інформаційного механізму реалізації сервісно-орієнтованої державної екологічної політики.

Аналіз останніх досліджень і публікацій. Значний внесок у розробку теорії сервісної політики внесли науковці Сполучених Штатів Америки та Великобританії, серед яких - Д. Осборн, Т. Геблер (D. Osborne, T. Gaebler), які наголошували на необхідності застосування в сфері публічного управління принципів менеджменту, що дозволило б підвищити ефективність управління. 
Серед українських дослідників тему менеджеризму (сервісної держави) розкрито в наукових роботах К. Дубич. Особливості функціонування сервісно-орієнтованої держави $є$ предметом розгляду таких науковців, як М. Дзевелюк, О. Євтушенко, О. Карпенко, В. Місюра та інші.

Попри значну кількість публікацій за темою формування сервісної держави, відзначимо, що сервісна орієнтованість держави в екологічній сфері $€$ відносно новим напрямом досліджень, тому наукових робіт з цієї теми натепер майже немає (здебільшого аналізуються засади екологічного права в Україні: В. Андрейцева, А. Гетьман, Л. Здоровко, Н. Кобецька, М. Краснова, Ю. Шемшученко).

Водночас на окрему увагу заслуговують праці, що безпосередньо стосуються проблеми формування і реалізації державної екологічної політики в Україні, зокрема О. Васюти, Б. Данилишина, Т. Іванової, О. Климчик, Н. Малиш, В. Наместнік.

Метою статті $є$ визначення змісту інформаційного механізму реалізації сервісно-орієнтованої державної екологічної політики в Україні.

Виділення не вирішених раніше частин загальної проблеми. Зростання громадської відповідальності та активності в екологічній сфері, з одного боку, зумовлює потребу участі в прийнятті державних рішень, контролі за діяльністю державних органів щодо охорони та раціонального використання природних ресурсів.

3 іншого - для досягнення консенсусу між владою та громадськістю в екологічній сфері їхня взаємодія має базуватися на прозорості й відкритості органів влади, співпраці й партнерстві, застосуванні сучасних інформацій- но-комунікаційних інструментів взаємодії як однієї з умов формування та реалізації ефективної сервісно-орієнтованої державної політики у сфері екології.

Недостатня наукова розробленість зазначених питань викликала науковий інтерес до 3'ясування змісту інформаційного механізму реалізації сервісно-орієнтованої державної екологічної політики.

Виклад основного матеріалу. Концепція сервісно-орієнтованої держави сформувалася у західноєвропейській науці у 80-х рр. XX століття, проте серед вітчизняних і зарубіжних науковців немає єдиного трактування терміна «сервісна держава» (табл. 1).

Отже, можна представити концепцію сервісної держави як певну модель розвитку, в основі якої розуміння ролі держави у виокремленні, акумуляції, моделюванні та задоволенні інтересів суспільства. Загалом вважаємо, що сервісні підходи можна застосувати в екологічній сфері, тому інформаційний механізм реалізації сервісно-орієнтованої державної екологічної політики розглянемо з точки зору взаємин держави з громадськістю у сфері екології за принципом «знизу - догори», коли громадськість, міжнародні фонди, об'єднання громадян постають ініціаторами ухвалення важливих рішень в екологічній сфері та беруть активну участь у розробці, прийнятті й контролі за їх реалізацією.

Формування сервісно-орієнтованої державної екологічної політики на сучасному етапі відбувається під впливом таких основних умов і процесів, як:

- децентралізація - процес передачі урядом повноважень на рівень, ближчий до споживача;

\section{Термін “сервісна держава» в роботах вітчизняних науковців}

Таблиця 1

\begin{tabular}{|l|l|}
\hline \multicolumn{1}{|c|}{ Автор / джерело } & \multicolumn{1}{|c|}{ Зміст терміна, ключові характеристики } \\
\hline $\begin{array}{l}\text { М. Дзевелюк } \\
\text { [2] }\end{array}$ & $\begin{array}{l}\text { «сервісна держава» - функціональна модель сучасної держави зорієнтована } \\
\text { на деконцентрацію і децентралізацію функцій, реалізація яких здійснюється } \\
\text { на конкурентних засадах у ситуативному режимі. }\end{array}$ \\
\hline $\begin{array}{l}\text { O. Євтушенко } \\
\text { [6] }\end{array}$ & $\begin{array}{l}\text { «сервісна держава» - по-перше, особлива політична форма організації } \\
\text { публічної влади, яка має спеціальний апарат управління, спрямований на } \\
\text { надання публічних послуг; по-друге, система соціальних гарантій належного } \\
\text { забезпечення добробуту особи та ї̈ прав і свобод. }\end{array}$ \\
\hline $\begin{array}{l}\text { O. Карпенко } \\
\text { [7] }\end{array}$ & $\begin{array}{l}\text { сервісно-орієнтована держава - це узгоджена модель суспільних відносин, } \\
\text { яка спрямована на розвиток державної політики, ціленаправленої на задово- } \\
\text { лення потреб суспільства (громадян) через надання якісних послуг, та скоор- } \\
\text { динована з довгостроковими цілями розвитку суспільства й держави. }\end{array}$ \\
\hline В. Місюра [11] & $\begin{array}{l}\text { соціально орієнтована сервісна політика -система заходів з розробки, впро-- } \\
\text { вадження та контролю за реалізацією напрямів державної політики, спрямо- } \\
\text { ваних на задоволення потреби громадськості в доступі до суспільних благ, яка } \\
\text { є узгодженою з довгостроковими цілями розвитку держави та суспільства. }\end{array}$ \\
\hline
\end{tabular}

Джерело: систематизовано автором 
- орієнтація на задоволення інтересів споживача послуг;

- залучення громадськості до роботи органів публічної влади, відповідальних за формування та реалізацію державної екологічної політики;

- використання комунікативних технологій планування та здійснення контролю, а також цифрових засобів комунікації влади і громадян.

На наш погляд, останні дві характеристики $€$ особливо важливими в роботі інформаційного механізму реалізації сервісно-орієнтованої державної екологічної політики України.

У Законі України «Про Основні засади (стратегію) державної екологічної політики України на період до 2030 року» [14] конкретизовано основні інструменти реалізації державної екологічної політики (рис. 1).

Переконані, що застосування зазначених інструментів сприятиме більш ефективному функціонуванню державних інституцій у сфері екології. За М. Красновою, такі заходи з реалізації державної екологічної політики, як контроль, моніторинг, екологічне інформування, віднесено до об'єктів екологічного права разом з природоохоронними заходами (роботи та послуги), що можуть здійснюватися державними/недержавними (господарськими, громадськими) органами й організаціями як у межах державних замовлень, так і на рівні договірного регулювання екологічних правовідносин [10, с. 11].

Натепер нормативно закріплено право громадян на участь в управлінні державними справами (ст. 38 Конституції України [9]). Крім того, досить широкий комплекс інструментів для громадської участі у розробці державної політики, у тому числі у сфері екології, контролю за дотриманням екологічного законодавства та визначення прозорості й відкритості пріоритетними принципами діяльності органів влади регулюється різними постановами Кабінету Міністрів України, зокрема від 03.11.2010 № 996.

міжскеторальне партнерство та залучення заінтересованих сторін

інформування та комунікауія

державне регулювання у сфері охорони навколиинього природного середовища

стратегічна екологічна оцінка та очінка впливу на довкілля

системи екологічного управління, екологічний аудит, екологічна сертифікауія та маркування продукціi

екологічний облік, технічне регулюваннл та облік у сфері охорони навколииньово природного середовица, природокористуєання та забезпечення екологічної безпеки

адаптауія законодавства Украйни у сфері охорони навколииньово природного середовица до законодавства Європейськово Союзу

безперервна екологічна освіта в інтересах збалансованого (сталого) розєитку

економічні та фінансові механізми, зокрема еколовічна модернізачія промислових підприемств иляхом зниюення ставки еколовічного податку

комплексний моніторине $i$ нагляд (контроль) у сфері охорони навколиинього природного середовича, рачіонального використання, єідтворення $і$ охорони природних ресурсік

міжснародне спієробітничтво у сфері охорони навколиинього природного середовича та забезпечення екологічної безпеки

Рис. 1. Сучасні інструменти реалізації сервісно-орієнтованої державної екологічної політики в Україні

Джерело: складено автором за [14] 
Важливим документом, який визначає екологічні права громадськості, є Орхуська конвенція (затверджена 25.06.1998) про доступ до інформації, участь громадськості у прийнятті рішень, які стосуються навколишнього природного середовища, доступ до правосуддя з питань, що стосуються довкілля. У контексті розгляду інформаційного механізму реалізації сервісно-орієнтованої державної політики України в екологічній сфері зазначимо, що Україною було ратифіковано Конвенцію у липні 1999 року, в якій ідеться про прагнення держави до забезпечення громадськості в отриманні доступу до інформації, сприяння екологічній просвіті та підвищенню рівня поінформованості громадськості щодо екологічних проблем [8].

Серед міжнародних нормативних актів, що регулюють питання надання екологічної інформації та сприяють євроінтеграційним процесам у природоохоронній галузі, варто окремо виділити Угоду про Асоціацію між Україною та ЄС та Директиву ЄС 2003/4/ $€ C$ від 28.01.2003 [3] щодо свободи доступу до інформації стосовно стану навколишнього середовища. Держави, що ратифікували Директиву, мають забезпечувати створення електронних баз даних, у яких містилася б інформація щодо навколишнього природного середовища і до яких громадськість мала б вільний доступ через громадську телекомунікаційну мережу, тобто інформація щодо навколишнього природного середовища має активно і систематично оприлюднюватися, зокрема за допомогою комп'ютерних телекомунікаційних та електронних технологій.

У Законі України «Про охорону навколишнього природного середовища» питанню екологічних прав громадянина присвячений окремий розділ: кожен громадянин має право брати участь в обговоренні і висуванні пропозицій до проєктів нормативно-правових актів у сфері захисту навколишнього природного середовища, право на вільний доступ до отримання екологічної інформації, право на участь у здійсненні стратегічної екологічної оцінки та у громадських обговореннях [15].

Розпорядженням Кабінету Міністрів України від 31.05.2017 № 616-р «Про схвалення Концепції реформування системи державного нагляду (контролю) у сфері охорони навколишнього природного середовища» визначено, що метою реформування $\epsilon$ створення ефективно діючої системи моніторингу навколишнього природного середовища і залучення громадськості до здійснення контролю у сфері запобігання екологічним правопорушенням. Одним із завдань Концепції $є$ удосконалення системи функціонування державної екологічної автоматизованої інформаційно-телекомунікаційної системи, доступу до екологічної інформації [18].

Участь громадськості у процесі формування і реалізації державної екологічної політики в Україні, доступність, своєчасність і достовірність екологічної інформації названо серед принципів такої політики на національному рівні [14]. На нашу думку, інформування і комунікація з громадськістю сприятимуть підвищенню рівня обізнаності громадян щодо діяльності органів влади в екологічній сфері, i, як наслідок, підвищуватимуть ефективність впровадження нормативно-правових актів, а також покращуватимуть стан навколишнього природного середовища.

Вагома роль у процесах формування і реалізації сервісно-орієнтованої екологічної політики належить Міністерству захисту довкілля та природних ресурсів України (далі Міністерство), що використовує нині у роботі з громадськістю такі форми (за даними офіційного вебсайту), як: звітність (публічні звіти про стан навколишнього середовища, ін.), запит на інформацію, електронні звернення, гаряча телефонна лінія, громадські обговорення (електронні консультації з громадськістю та вивчення громадської думки), громадська експертиза.

Ініціатором громадських обговорень проєкту того чи іншого рішення у сфері екології можуть бути як громадські профільні екологічні об'єднання, так і ключові державні інституції, що займаються формуванням та реалізацією державної екологічної політики в Україні.

Інструмент електронних консультацій 3 громадськістю дає змогу брати участь в обговоренні проєктів рішень Кабінету Міністрів України у сфері екології. Крім того, для громадян $є$ можливість надіслати запит на інформацію або електронне звернення. При профільному Міністерстві діє громадська приймальня та гаряча телефонна лінія.

Громадська експертиза як механізм контролю з боку громадськості у процесі оцінки впливу на довкілля затверджена в ст. 7 Закону України «Про оцінку впливу на довкілля» і проводиться з метою виявлення, збирання та врахування зауважень і пропозицій громадськості до планованої діяльності [16]. Отже, висновки громадської експертизи можуть лише враховуватись у проведенні державної екологічної експертизи, прийнятті рішень, тобто йдеться про рекомендаційний, а не обов'язковий їх характер.

Серед основних принципів інформаційних відносин - гарантованість права на інформа- 
цію; відкритість, доступність, достовірність, повнота інформації (ст. 2 Закону України «Про інформацію» [13]). Насамперед ідеться про належне інформування населення, забезпечення якого можна розцінювати основою для залучення громадськості до прийняття управлінських рішень.

Однак функції органів влади у цьому напрямі можуть відрізнятися, це може бути або неперешкоджання в отриманні інформації, або активне її поширення. 3 одного боку, незважаючи на нормативне закріплення можливості брати участь у прийнятті рішень органами влади, громадськість не завжди активна. Відповідно до результатів дослідження Фонду «Демократичні ініціативи» ім. Ілька Кучеріва та соціологічної служби Центру Разумкова у грудні 2018 року досить незначна кількість громадян вважає себе залученими до активної громадської діяльності. Впродовж 2013-2018 рр. цей показник варіюється у межах 8-10\% [1], що вказує на низький рівень громадської участі та свідчить про необхідність змін у реалізації сервісної політики.

3 іншого боку, активність громадян після Революції Гідності в Україні значно зросла і можна погодитись з тим, що громадські екологічні організації є одними із найбільш активних, тому безпосередньо впливають на цифрові трансформації в країні та збільшення прозорості діяльності органів влади, відповідальних за формування і реалізацію екологічної політики. Про зростання кількості громадян (з 5-6\% до 10\%), стурбованих екологічною політикою, відзначено, зокрема, у результатах дослідження Київського міжнародного інституту соціології у травні 2018 року [4].

У цьому контексті створення загальнодержавної автоматизованої системи «Відкрите довкілля» можна вважати значним кроком у напрямі забезпечення прав громадян на отримання екологічної інформації. Вона являє собою систему управління екологічною інформацією для забезпечення дотримання екологічних прав громадян і надання вільного доступу до екологічної інформації про стан навколишнього природного середовища, екологічні ризики/загрози із застосуванням телекомунікаційних технологій та глобальних інформаційних мереж [17]. Серед завдань - впровадження цифрового врядування, цифровізація управлінської діяльності у сфері надання адміністративних послуг, оприлюднення відкритих даних щодо екологічної інформації.

Доступ до інформації щодо екологічного становища, стану довкілля, екологічних ризиків, які можуть вплинути на життєдіяльність, є невід'ємним правом громадянина. Разом із тим погоджуємося, що «питання доступу до інформації $€$ необхідним і безумовним складником для здійснення громадського контролю в галузі охорони навколишнього середовища [12, с. 9]. Тому належне інформування громадян про екологічну ситуацію, заходи екологічного спрямування для широкої громадськості сприятимуть, по-перше, більш ефективній взаємодії органів влади і громадськості, а по-друге, реалізації інформаційного механізму сервісно-орієнтованої державної політики в екологічній сфері.

Висновки. Спираючись на вищесказане, зміст інформаційного механізму реалізації сервісно-орієнтованої державної екологічної політики в Україні можна представити як систему організаційних, правових, програмно-технологічних засобів, за допомогою яких забезпечується прийняття владних рішень у сфері екології шляхом використання інформаційно-комунікаційних зв'язків між владою та громадськістю. Відповідно до такого трактування особливо зростає роль і значення активних громадян, що мають оволодіти певними екологічними знаннями задля сприяння екологічному оздоровленню нашої країни і поліпшенню життя населення. Держава при цьому має виконувати роль служіння громадянам, а діяльність її інститутів базуватися на ставленні до громадян як до споживачів цих послуг.

Таким чином, ефективність функціонування сучасної державної екологічної політики варто оцінювати з точки зору ефективності задоволення потреб споживачів, а також швидкості й ефективності обміну інформаційними потоками між учасники процесу, в тому числі з допомогою сучасних інформаційно-комунікаційних технологій. 3 одного боку, учасником згаданого процесу виступає держава та ключові інституції в сфері екології, що вибудовують політику довкола нагальних екологічних потреб суспільства, роз'яснення основних прав і обов'язків у сфері екології, просувають екологічні цінності та розкривають їх зміст, а 3 іншого - активні громадяни (громадські організації), що акцентують увагу державних інституцій на питаннях, що потребують негайного вирішення, залучені до процесу формування та реалізації екологічної політики.

Загалом проведений аналіз основних нормативно-правових документів у зазначеній сфері та нормативного закріплення екологічних прав громадян дає підстави стверджувати, що державну екологічну політику в Україні можна вважати сервісно-орієнтованою через спрямованість держави на задоволення 
потреб громадськості, у тому числі щодо отримання доступу до екологічної інформації. Втім, незважаючи на загалом позитивні тенденції, Україна ще перебуває на стадії становлення сервісно-орієнтованої державної екологічної політики, саме в практичній реалізації європейського принципу ставлення до громадянина як до споживача послуг.

\section{ЛІТЕРАТУРА:}

1. Громадська активність громадян України. 2018 рік (дослідження). URL: https://dif.org.ua/article/ gromadska-aktivnist-gromadyan-ukraini (дата звернення: 01.10.2020).

2. Дзевелюк М.В. Сервісна держава як фрункціональна модель сучасної держави. Актуальні проблеми держави і права : збірник наукових праць. Вип. 78. 2017. С. 60-67.

3. Директива Європарламенту та Ради щодо свободи доступу до інфрормації стосовно стану навколишнього середовища № 2003/4/€C. URL: https:// menr.gov.ua (дата звернення: 01.10.2020).

4. Дослідження Київського міжнародного інституту соціології. 2018 рік. URL: https://www.kiis.com.ua (дата звернення: 01.04.2019).

5. Дубич К.В. Менеджералізм у наданні державних послуг населенню в соціальній сорері: досвід Великобританії. Публічне адміністрування : теорія та практика. ДРІДУ НАДУ. 2012. № 186. Випуск 2 (8). URL: http://dridu.dp.ua/zbirnik/2012-02(8)/12dkvsdv.pdf.

6. Євтушенко О.М. Роль державної влади і місцевого самоврядування у розбудові сервісної держави 3 надання якісних публічних послуг. Наукові праці. Науково-методичний журнал. Політичні науки. Миколаїв : ЧДУ ім. П. Могили, 2009. С. 32-37.

7. Карпенко О.В. Механізми фрормування та реалізації сервісно-орієнтованої державної політики в Україні : автореср. дис. на здобуття наук. ступеня д.н. держ. упр. : 25.00.02. Київ. НАДУ, 2016. 40 с.

8. Конвенція про доступ до інформації, участь громадськості в процесі прийняття рішень та доступ до правосуддя 3 питань, що стосуються довкілля (Орхуська конвенція, 25.06.1998). URL: https://zakon.rada.gov.ua/laws/show/994 015\#Text (дата звернення: 09.10.2020).

9. Конституція України : Закон України від 28.06.1996 № 254k/96-BP. URL: http://zakon2.rada.gov. иа (дата звернення: 01.04.2019).

10. Краснова М. Стан та перспективи розвитку вчення про об'єкти екологічного права: науково-методологічні аспекти. Вісник КНУ ім. Шевченка. Юридичні науки. № 2 (96). 2013. С. 8-12.

11. Місюра В.Я. Методологічні засади аналізу соціально орієнтованої сервісної політики держави. Вісник НАДУ. 2015. № 4. С. 12-17.

12. Наместнік В. Громадські організації як суб'єкти фрормування і реалізації державної екологічної політики : автореф. дис. на здобуття наук. ступеня к.н. держ. упр. : 25.00.02. Київ : НАДУ, 2015. 23 с.

13. Про інформацію : Закон України від 02.10.1992 № 2657-XII. URL: https://zakon.rada.gov.ua/laws/ show/2657-12 (дата звернення: 01.04.2019).

14. Про Основні засади (стратегію) державної екологічної політики України на період до 2030 року : Закон України. URL: https://zakon.rada.gov.ua (дата звернення: 07.10.2020).

15. Про охорону навколишнього природного середовища : Закон України від 25.06.1991 № 1264-XII. URL: https://zakon.rada.gov.ua/laws/show/1264-12\# Text (дата звернення: 10.04.2019).

16. Про оцінку впливу на довкілля : Закон України від 23.05.2017 № 2059-19. URL: https://zakon.rada.gov. ua/laws/show/2059-19 (дата звернення: 09.10.2020).

17. Про схвалення Концепції створення загальнодержавної автоматизованої системи «Відкрите довкілля» : Розпорядження Кабінету Міністрів України від 07.11.2018 № 825-p. URL: https://www.kmu.gov.ua (дата звернення: 01.04.2019).

18. Про схвалення Концепції реформування системи державного нагляду (контролю) у сорері охорони навколишнього природного середовища : Розпорядження КМУ від 31.05.2017 № 616-p. URL: https://zakon.rada.gov.ua/laws/show/616-2017\%D1\%80\#n2 (дата звернення: 01.04.2019).

19. Osborne D., Gaebler T. Reinventing government. How the entrepreneurial spirit is transforming the public sector. Reading, MA: AddisonWesley, 1992. 432 p. 